\title{
Clinical, pathological and epidemiological aspects of outbreaks of bluetongue disease in sheep in the central region of Rio Grande do Sul ${ }^{1}$
}

\author{
Ronaldo M. Bianchi² ${ }^{2 *}$ Welden Panziera², Tatiane C. Faccin², Gisane L. de Almeida ${ }^{3}$, \\ Juliana F. Cargnelutti ${ }^{4}$, Eduardo F. Flores ${ }^{4}$, Glaucia D. Kommers ${ }^{5}$ and Rafael A. Fighera ${ }^{5}$
}

\begin{abstract}
Bianchi R.M., Panziera W., Faccin T.C., Almeida G.L., Cargnelutti J.F., Flores E.F., Kommers G.D. \& Fighera R.A. 2017. Clinical, pathological and epidemiological aspects of outbreaks of bluetongue disease in sheep in the central region of Rio Grande do Sul. Pesquisa Veterinária Brasileira 37(12):1443-1452. Departamento de Patologia, Universidade Federal de Santa Maria, Av. Roraima 1000, Santa Maria, RS 97105-900, Brazil. E-mail: romichelbianchi@yahoo.com.br

This article describes the clinical, pathological and epidemiological aspects of 17 outbreaks of bluetongue (BT) disease in sheep occurring between December 2014 and July 2015 in the central region of Rio Grande do Sul state (RS), southern Brazil. Affected farms were visited for clinical examination, necropsy, sample collection and epidemiological investigation. The outbreaks were seasonal and occurred during the summer and autumn. A total of 180 sheep (20.4\%) out of 884 in 17 small herds were affected. All ages of Texel and mixed breed sheep were affected. However, lambs (younger than one year) had higher morbidity than adult sheep. The most frequent clinical signs were anorexia, lethargy, loss of body condition, facial swelling mainly involving the lips, and greenish seromucous or mucous nasal discharge. Pulmonary lesions characterized by edema were the most prevalent findings; however, erosive and ulcerative lesions in the upper gastrointestinal tract, as well as cardiac, skeletal muscle and esophageal striated muscle necrosis, and hemorrhage in the pulmonary artery were also frequent. The bluetongue virus (BTV) genome was detected by RT-PCR in blood and tissue samples (spleen and lungs) of 21 animals from 17 outbreaks. The virus involved in the outbreak 3 was subsequently isolated and shown to belong to serotype 17, for the first time reported in Brazil. In summary, our data support the BTV genotype 17 as the etiological agent of the outbreaks and indicate that the central region of RS is an area at risk for BT in sheep, a disease previously not recognized in the region.
\end{abstract}

INDEX TERMS: Bluetongue disease, Rio Grande do Sul, diseases of sheep, bluetongue virus, natural infection, veterinary pathology.

\footnotetext{
${ }^{1}$ Received on March 26, 2017.

Accepted for publication on November 17, 2017.

Part of the requirements for the fulfillment of the Master's degree by the first author.

${ }^{2}$ Programa de Pós-Graduação em Medicina Veterinária, área de concentração em Patologia e Patologia Clínica Veterinária, Centro de Ciências Rurais (CCR), Universidade Federal de Santa Maria (UFSM), Bairro Camobi, Santa Maria, RS 97105-900, Brazil. *Corresponding author: romichelbianchi@ yahoo.com.br

${ }^{3}$ Secretaria Estadual da Agricultura, Pecuária e Irrigação (SEAPI), Av. Fernando Ferrari 1996, Santa Maria, RS 97050-800, Brazil.

${ }^{4}$ Departamento de Medicina Veterinária Preventiva, UFSM, Av. Roraima 1000, Santa Maria, RS 97105-900, Brazil.

${ }^{5}$ Departamento de Patologia, Centro de Ciências da Saúde (CCS), UFSM, Av. Roraima 1000, Santa Maria, RS 97105-900, Brazil.
}

RESUMO-- [Aspectos epidemiológicos, clínicos e patológicos de surtos de língua azul em ovinos na Região Central do Rio Grande do Sul.] O objetivo deste artigo é descrever os aspectos epidemiológicos, clínicos e anatomopatológicos de 17 surtos de língua azul (BT) em ovinos, que ocorreram entre dezembro de 2014 a julho de 2015, na Região Central do Rio Grande do Sul, Brasil. Para isso, foram realizadas visitas as propriedades nas quais ocorreram surtos da doença para investigação epidemiológica e clínica, realização de necropsias e coleta de amostras. Os surtos foram sazonais e ocorreram durante o verão e outono. Em 17 pequenos rebanhos, de um total de 884 ovinos, 180 adoeceram $(20,4 \%)$. Ovinos de todas as faixas etárias, 
da raça Texel e sem raça definida, foram acometidos. Entretanto, ovinos com menos de um ano de idade tiveram taxa de morbidade maior do que ovinos com um ano ou mais. Os sinais clínicos mais frequentes caracterizaram-se por anorexia, apatia, acentuada perda de peso, edema facial, envolvendo principalmente os lábios, e secreção nasal seromucosa ou muco-esverdeada. Lesões pulmonares, caracterizadas por edema, foram as mais prevalentes. Porém, lesões erosivas e ulcerativas no trato gastrointestinal superior, assim como necrose da musculatura cardíaca e esquelética e do músculo estriado do esôfago e hemorragia na artéria pulmonar foram frequentes. 0 genoma do BTV foi detectado por RT-PCR em amostras de sangue e tecidos (baço e pulmão) de 21 animais de 17 surtos. 0 vírus envolvido no surto 3 foi subsequentemente isolado e pertence ao sorotipo 17 , que pela primeira vez é descrito no Brasil. Em síntese, nossos dados permitem concluir que o BTV é o agente causador dos surtos e indicam que a Região Central do RS é uma área de risco para a ocorrência de BT em ovinos, uma doença, até então, não reconhecida nessa região.

TERMOS DE INDEXAC̦ÃO: Epidemiologia, surtos de língua azul, ovinos, Rio Grande do Sul, doenças de ovinos, vírus da língua azul, infecção natural, patologia veterinária.

\section{INTRODUCTION}

Bluetongue (BT) is an infectious, non-contagious disease caused by bluetongue virus (BTV), a segmented, non-enveloped double-stranded RNA virus belonging to the genus Orbivirus, family Reoviridae. BTV is primarily transmitted by biting midges of the genus Culicoides (Anthony et al. 2007, Radostits et al. 2007, Riet-Correa 2007, Caparole et al. 2011, Alfieri et al. 2012). The disease affects domestic and wild ruminants, however, the clinical manifestations are seen almost exclusively in sheep and rarely in cattle, which may act as reservoirs of the virus (Maclachlan et al. 1990, Gibbs \& Greiner 1994, Barnard et al. 1998, Maclachlan et al. 2009, Alfieri et al. 2012).

According to the Brazilian Department of Agriculture (MAPA 2013) BT is considered an immediately no-tifiable disease. It is included in the list of the World Orga $\neg$ nization for Animal Health (OIE 2015).

Currently, 27 BTV serotypes are recognized worldwide (Zientara et al. 2014, Jenckel et al. 2015, Schulz et al. 2016), mainly in Europe, United States, Australia and South Africa (Maclachlan et al. 2009, Maan et al. 2012, Maclachlan \& Mayo 2013). In Brazil, some BTV serotypes have been reported. The serotype 4 was isolated in 1980 in Brazilian cattle kept in quarantine in the United States (Groocock \& Campbell 1982) and, more recently (2013 and 2014), in sheep in the States of Rio de Janeiro (Balaro et al. 2014), Minas Gerais (Lima et al. 2016) and Rio Grande do Sul (RS) (Guimarães 2015). The serotype 12 was isolated in sheep and goats in 2001 in the State of Paraná (Clavijo et al. 2002) and in sheep in 2009 in RS (Antoniassi et al. 2010). More recently, in 2015 and 2016, the serotypes 3, 14, 18, 19 and 22 were isolated in deer in the State of Paraná (OIE 2016). The first serological evidence of BTV infection in South America was in Brazil in 1978 and, since then, several serological surveys have indicated that the infection is widespread in the country. Nonetheless, most infections probably go unnoticed, without overt clinical manifestations (Lager 2004, Costa et al. 2006, Lobão et al. 2014).

The aim of this report is to describe the clinical, epidemiological, and pathological aspects of 17 outbreaks of BT disease in sheep that occurred between 2014 and 2015 in the central region of RS, Southern Brazil, to emphasize its importance to this region.

\section{MATERIALS AND METHODS}

Clinical and epidemiological data were obtained from farmers and veterinarians. The visits to affected farms were supported by veterinarians from the Animal Health Service of Secretaria Estadual da Agricultura, Pecuária e Irrigação (SEAPI) of RS State. The farms were numbered from F1 to F17 and the cases occurred in each farm were considered as an outbreak (01 to 017). Seventeen of 39 sheep that died in the outbreaks were necropsied, and they were identified as S1-S17. Fragments of several organs were collected at necropsy, fixed in $10 \%$ buffered formalin, processed routinely for histology, and stained with hematoxylin-eosin (HE). Spleen and lung samples from nine necropsied sheep were packed in RNA Later solution (Thermofisher Scientific, Ambion, Waltham, MA USA), and maintained under refrigeration. In addition, whole blood samples were collected in tubes with EDTA of sheep from most farms, with the exception of F12, F15, F16, and F17, and placed in refrigerated cooler.

Blood, spleen, and lung samples were submitted to BTV detection by reverse transcription - polymerase chain reaction (RTPCR). Total RNA extraction was performed using Trizol reagent (Thermofisher Scientific, Life Technologies, Waltham, MA USA). Before complementary DNA confection (using SuperScript III First-Strand Synthesis Supermix kit by Thermofisher Scientific, Life Technologies, Waltham, MA USA), total RNA were heat at $95^{\circ} \mathrm{C}, 5 \mathrm{~min}$. cDNA were submitted to PCR to amplify $104 \mathrm{pb}$ of BTV genome segment 1 [VP1] (primers forward: 5'-3': GCG AAG TGT GGA CAT GAA GC, e reverse 5'-3': TCC TGC GGT ACG TAA CAA CC). The PCR reaction was performed, using 100ng of cDNA, $0,4 \mu \mathrm{M}$ of each primer, $1,5 \mathrm{mM}$ of $\mathrm{MgCl}_{2}, 10 \mathrm{mM}$ of dNTPs, $10 \%$ of buffered, and $1 \mathrm{U}$ of Taq DNA polymerase (Thermofisher Scientific, Life Technologies, Waltham, MA USA) under the following conditions: $95^{\circ} \mathrm{C}$ for $8 \mathrm{~min}$, followed by 40 cycles of $95^{\circ} \mathrm{C}$ for $45 \mathrm{sec}$, $59^{\circ} \mathrm{C}$ for $30 \mathrm{sec}$, and $72^{\circ} \mathrm{C}$ for $45 \mathrm{sec}$; and a terminal extension of $7 \mathrm{~min}$ at $72^{\circ} \mathrm{C}$. The PCR products were visualized in $2 \%$ agarose gel, stained with GelRed ${ }^{\circledR}$ gel (Biotium, CA, EUA), and analyzed under ultraviolet light. For all reactions a positive control (BTV amplified in BHK-21 cells) and a negative control (ultrapure water) were used. Serotype determination was performed according to Maan et al. (2012) at the Laboratório de Pesquisa em Virologia Animal da Universidade Federal de Minas Gerais (UFMG).

\section{RESULTS}

\section{Epidemiology}

The 17 outbreaks occurred in farms from Central Region of RS, in the counties of Itaara ( $n=9)$, Santa Maria ( $n=3)$, São Pedro do Sul (n=1), Pinhal Grande $(n=2)$ and Jaguari $(n=2)$ (Fig.1), between late spring/early summer (December 2014) until early winter (July 2015). In the 17 outbreaks, 884 sheep were at risk and 180 got sick (general morbidity rate of 20.4\%) and 39 died (general mortality and lethality rates of $4.4 \%$ and $21.7 \%$, respectively). All ages of Texel and 
mixed breed sheep were affected, however, lambs under one year-old had higher morbidity (28.7\% [78/272]), mortality (8.4\% [23/272]) and lethality rates (59\% [23/39]) than sheep with one year-old or more $(16.7 \%$ [102/612], $2.6 \%$ [16/612], 41\% [16/39], respectively). Data for each farm, related to the localization and period of outbreaks, number of sheep, age group and morbidity, mortality and lethality rates are specified in Table 1.

\section{Clinical signs}

The clinical course ranged from three to seven days in sheep that died (average of five days) and around 10 days in sheep that recovered. Clinical signs observed in $100 \%$ of the outbreaks included anorexia, lethargy, loss of condition, facial swelling, mainly involving the lips, and greenish seromucous or mucous nasal discharge (Fig.2A) with crusting around the nares. Other frequent clinical signs $(65 \%$ [11/17]) included respiratory distress, tachypnea, cough, pulmonary rattle, hyperemic or cyanotic oral mucosa, and ulcerative lesions in the oral cavity, mainly involving the hard palate. Eventually (three outbreaks), the sheep had swollen and cyanotic tongue. Less common clinical signs
(35\% [6/17]) included fever, salivation, food regurgitation, and stiffness with or without lameness. In many farms, the veterinarians responsible for the animal care, recommended the administration of broad-spectrum antibiotics, associated with non-steroidal anti-inflammatory drugs, once a day for 3-5 days.

\section{Gross lesions}

Greenish seromucous or mucous nasal discharge in varying amounts and pulmonary involvement were frequent (88\% of necropsied sheep [15/17]). The lung lesions included pulmonary edema, characterized by an increased, not collapsed, heavy, reddened and shiny lung, with the rib impressions. Varied amounts of liquid and foam were observed in the trachea and large bronchi (Fig.2B) and, in six sheep, food also was present (Fig.2C). Many of these sheep had cranioventral pulmonary consolidation with increased consistency and redness of the cranial lobes (Fig.2D).

Lesions in the oral cavity were common $(60 \%$ of necropsied sheep [10/17]), and included lips swelling, sometimes with hemorrhagic and ulcerative areas, and ulcers on the hard palate, mainly involving the pulvinus dentalis

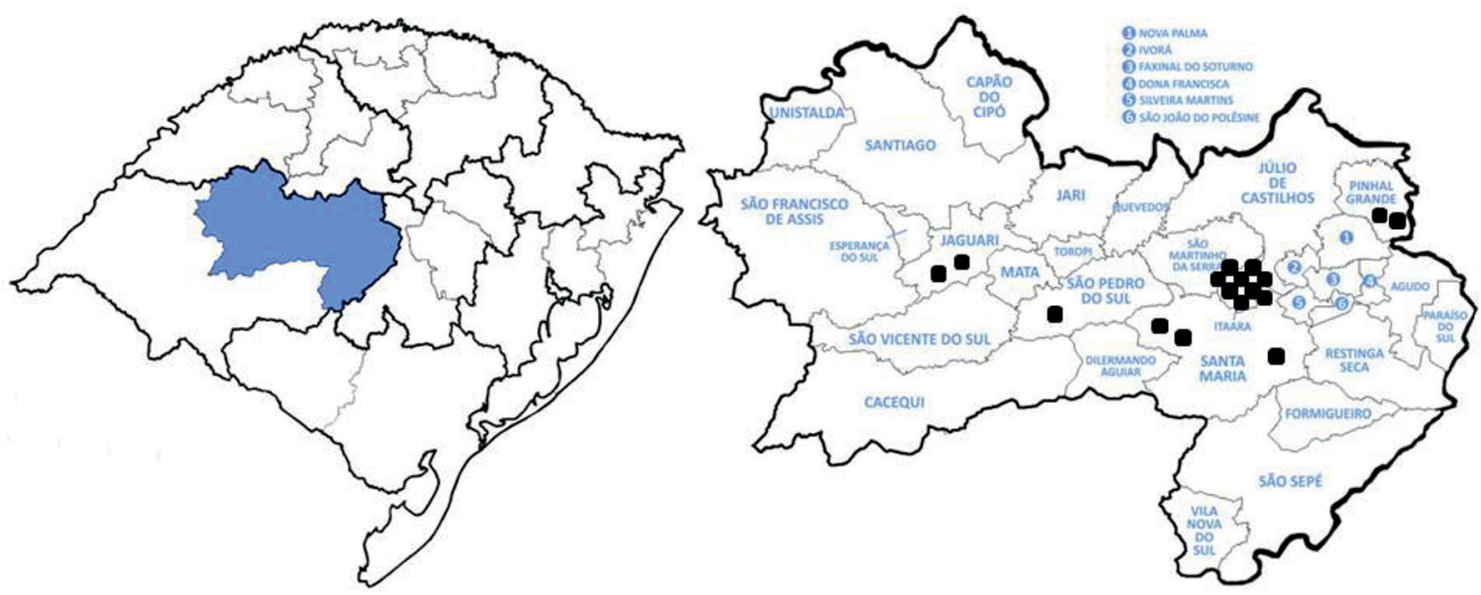

Fig.1. Map of central region of Rio Grande do Sul, Brazil, showing the distribution of the outbreaks.

Table 1. Population and age of the sheep at risk, and morbidity, mortality, lethality rates of bluetongue outbreaks

\begin{tabular}{|c|c|c|c|c|c|c|}
\hline Outbreak and city & Period of outbreak & Total number of sheep & Age of sickened sheep & Morbidity (\%) & Mortality (\%) & Lethality (\%) \\
\hline (01) Itaara, RS & Dez/2014 - Feb/2015 & $80\left(29^{a}+51^{b}\right)$ & $10\left(3^{a}+7^{b}\right)$ & $12.5(10 / 80)$ & $2.5(2 / 80)$ & $20(2 / 10)$ \\
\hline (O2) Santa Maria, RS & Dez/2014 - Feb/2015 & $197(40+157)$ & $31(9+22)$ & $15.7(31 / 197)$ & $5.6(11 / 197)$ & $35.5(11 / 31)$ \\
\hline (03) Itaara, RS & Jan/2015 - Feb/2015 & $11(5+6)$ & $7(3+4)$ & $63.6(7 / 11)$ & $9.1(1 / 11)$ & $14.3(1 / 7)$ \\
\hline (05) Itaara, RS & Jan/2015 - Feb/2015 & $41(17+24)$ & $17(6+11)$ & $41.5(17 / 41)$ & $0(0 / 41)$ & $0(0 / 0)$ \\
\hline (06) Itaara, RS & Feb/2015 & $19(6+13)$ & $1(0+1)$ & $5.3(1 / 19)$ & $5.3(1 / 19)$ & $100(1 / 1)$ \\
\hline (07) Itaara, RS & Jan/2015 - Feb/2015 & $28(15+13)$ & $4(1+3)$ & $14.3(4 / 28)$ & $7.14(2 / 28)$ & $50(2 / 4)$ \\
\hline (010) Itaara, RS & Feb/2015 - Mar/2015 & $11(2+9)$ & $3(2+1)$ & $27.3(3 / 11)$ & $0(0 / 11)$ & $0(0 / 0)$ \\
\hline (011) São Pedro do Sul, RS & Feb/2015 - Mar/2015 & $121(38+83)$ & $55(20+35)$ & $45.4(55 / 121)$ & $1.6(2 / 121)$ & $3.6(2 / 55)$ \\
\hline (012) Pinhal Grande, RS & Mar/2015 - Apr/2015 & $19(14+5)$ & $10(8+2)$ & $52.6(10 / 19)$ & $15.8(3 / 19)$ & $30(3 / 10)$ \\
\hline (013) Pinhal Grande, RS & Mar/2015 - Apr/2015 & $40(13+27)$ & $1(0+1)$ & $2.5(1 / 40)$ & $0(0 / 0)$ & $0(0 / 0)$ \\
\hline (014) Itaara, RS & Apr/2015 - May/2015 & $28(8+20)$ & $8(3+5)$ & $28.6(8 / 28)$ & $0(0 / 0)$ & $0(0 / 0)$ \\
\hline (015) Santa Maria, RS & May/2015 - Jun/2015 & $124(30+94)$ & $12(12+0)$ & $9.7(12 / 124)$ & $1.6(2 / 124)$ & $16.7(2 / 12)$ \\
\hline (016) Jaguari, RS & May/2015 - Jun/2015 & $15(5+10)$ & $8(4+4)$ & $53.3(8 / 15)$ & $46.7(7 / 15)$ & $87.5(7 / 8)$ \\
\hline
\end{tabular}

$\overline{\mathrm{O}=\text { outbreak, }}{ }^{\mathrm{a}}$ number of lambs under one year of age, ${ }^{\mathrm{b}}$ number of sheep with one year of age or more. 

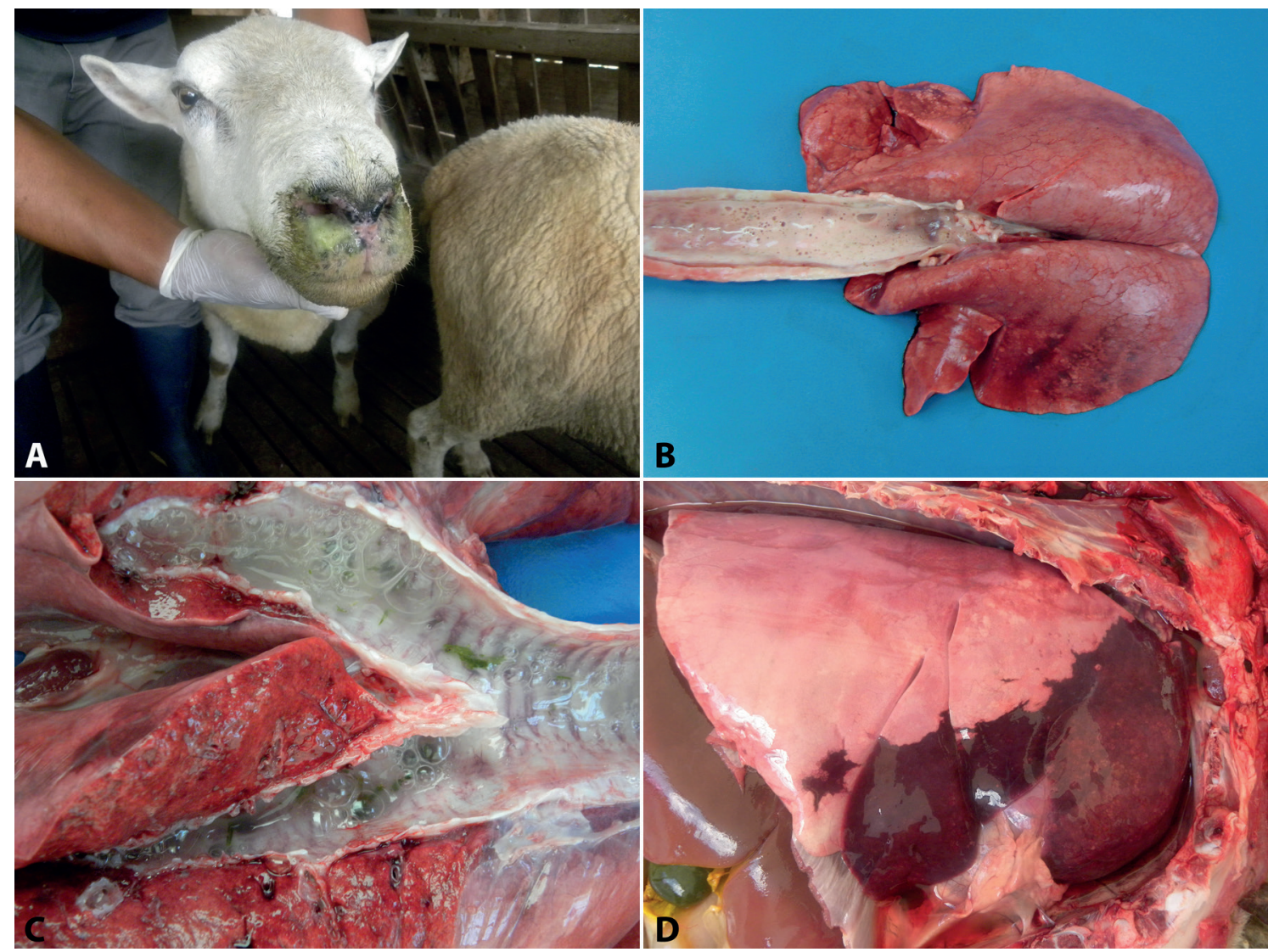

Fig.2. Bluetongue in sheep. (A) Face. Abundant greenish mucous nasal discharge. Note the marked facial swelling, mainly on the upper lip. (B) Lung and trachea. Increased, not collapsed, heavy, reddened, and shiny lung, with the rib impressions. In the trachea there is moderate amount of foamy content (edema). (C) Trachea and large bronchi. Mucous exsudate admixed with food fragments (aspirate material). (D) Thoracic cavity. The right cranial, and middle lobes are markedly firm and reddened (cranioventral pulmonary consolidation).

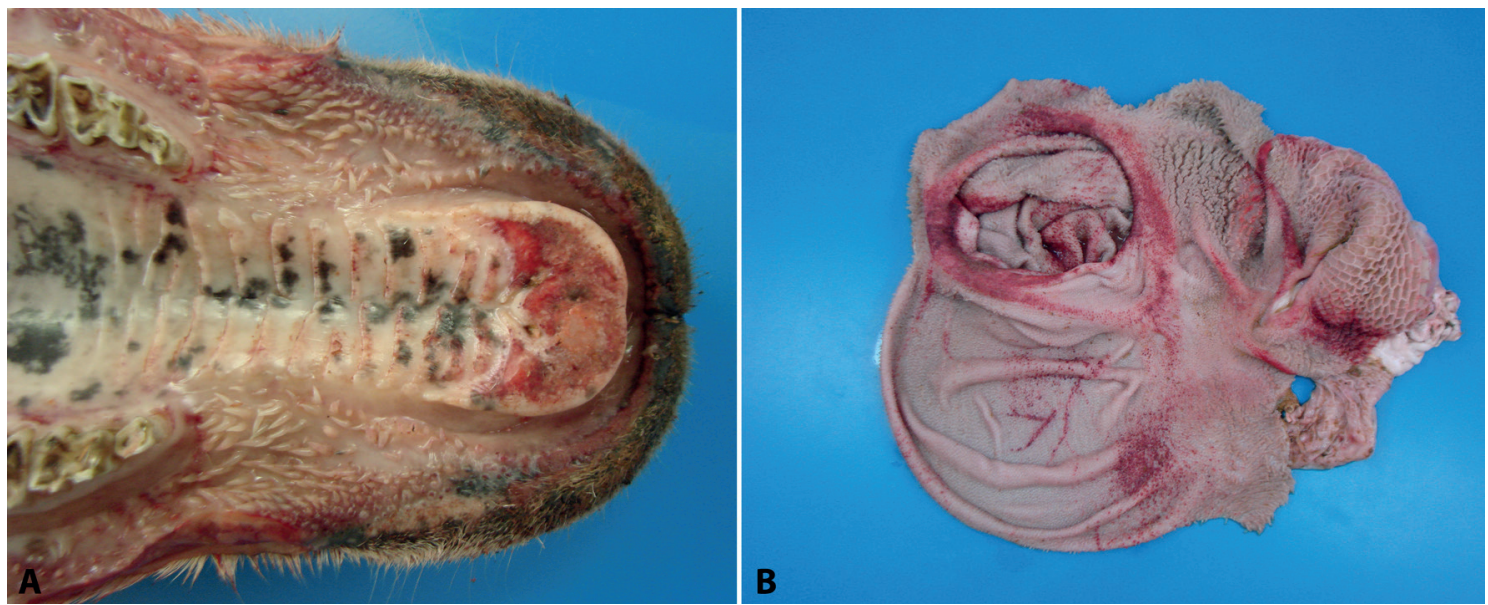

Fig.3. Bluetongue in sheep. (A) Oral cavity. Ulcerative and hemorrhagic areas on the upper lip, and hard palate, mainly involving pulvinus dentalis. Note that the lip is markedly thick. (B) Rumen and reticulum. Multifocal hemorrhages on rumen pillars and reticulum mucosa.

(Fig.3A), and hemorrhage and rounding of oral conic buds. The tongue, in three sheep, was swollen and cyanotic. Hemorrhagic and ulcerative areas in the dorsal surface of the tongue were common. Lesions involving other portions of the digestive tract were commonly seen in the rumen, and less frequently in the esophagus, reticulum, omasum and abomasum. Ruminal lesions were characterized by hemor- rhages in the mucosa, mainly affecting the pillars (Fig.3B), and ulcers in the apex of the papillae. Similar lesions were seen in the reticulum and omasum in two sheep. In three sheep, the esophagus was dilated and with hemorrhagic areas in the adventitia. The lesions in the abomasum were associated with parasitism by Haemonchus contortus in four sheep. 

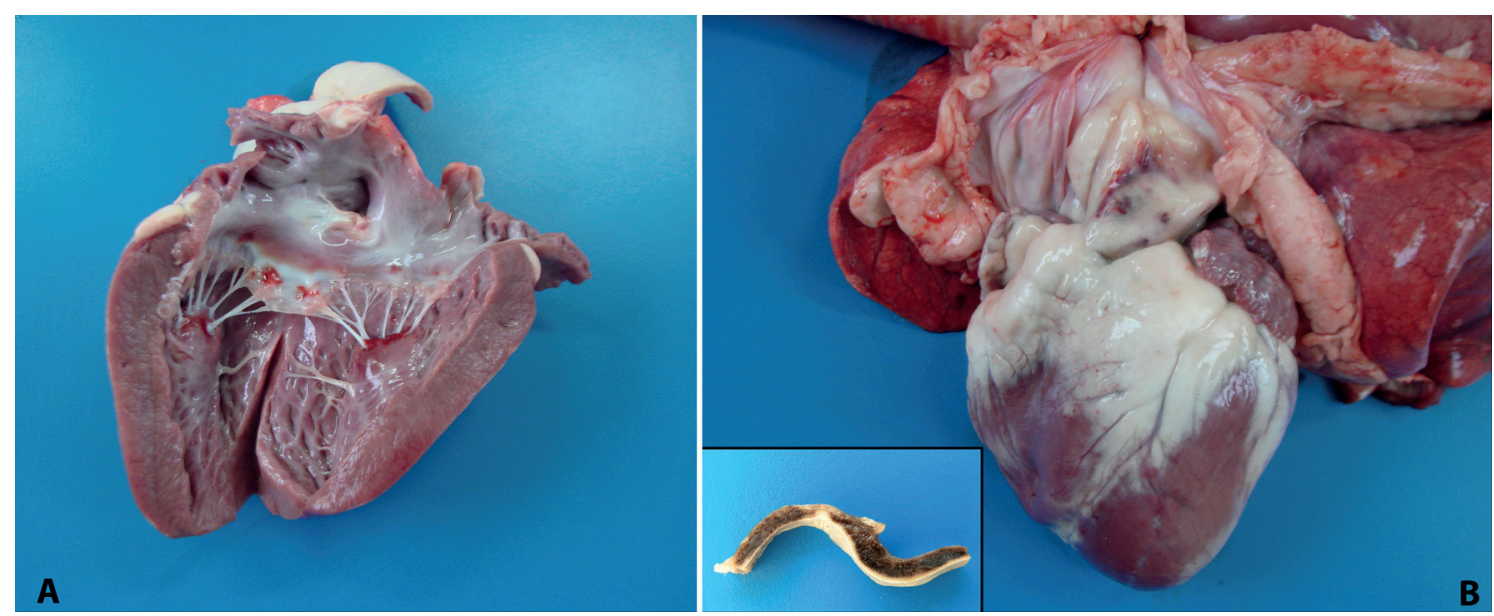

Fig.4. Bluetongue in sheep. (A) Heart. Symmetrical bilaterally hemorrhage affecting papillary muscles. (B) Hemorrhages in the pulmonary artery. Inset, cut surface with transmural hemorrhage.

Table 2. Distribution and severity of gross lesions

\begin{tabular}{|c|c|c|c|c|c|c|c|c|c|c|c|c|c|c|c|c|c|}
\hline Sheep & $\mathrm{S} 1$ & $\mathrm{~S} 2$ & S3 & $\mathrm{S} 4$ & S5 & S6 & S7 & S8 & S9 & $\mathrm{S} 10$ & S11 & $\mathrm{S} 12$ & $\mathrm{~S} 13$ & $\mathrm{~S} 14$ & S15 & S16 & S17 \\
\hline \multicolumn{18}{|l|}{ Organs } \\
\hline Lips & - & - & + & + & +++ & + & ++ & + & + & + & ++ & ++ & ++ & ++ & + & ++ & - \\
\hline Hard palate & - & - & - & - & +++ & - & +++ & ++ & - & - & +++ & - & - & - & - & - & - \\
\hline Tongue & - & - & ++ & ++ & ++ & + & ++ & + & - & - & ++ & - & - & - & + & - & - \\
\hline Cheeks & - & - & - & - & ++ & - & ++ & - & - & - & ++ & - & - & - & - & - & - \\
\hline Esophagus & - & - & - & - & - & + & - & - & - & - & - & + & + & - & - & - & - \\
\hline Rumen & - & - & - & - & +++ & - & ++ & ++ & ++ & - & +++ & - & - & - & - & - & +++ \\
\hline Reticulum & - & - & - & - & ++ & - & - & + & - & - & - & - & - & - & - & - & - \\
\hline Omasum & - & - & - & - & + & - & - & + & - & - & - & - & - & - & - & - & - \\
\hline Abomasum & - & ++ & - & - & - & + & - & - & - & - & - & - & - & ++ & ++ & - & - \\
\hline Heart & - & - & ++ & + & +++ & + & +++ & - & ++ & - & +++ & + & + & + & + & - & + \\
\hline Pulmonary artery & - & - & ++ & - & +++ & + & +++ & - & - & - & +++ & + & - & + & + & - & - \\
\hline Lung & + & +++ & ++ & ++ & +++ & +++ & - & + & + & ++ & +++ & ++ & +++ & +++ & +++ & ++ & +++ \\
\hline Skeletal muscles & - & - & - & - & - & - & - & - & - & - & +++ & - & - & - & - & - & - \\
\hline Lymph nodes & - & - & - & - & - & + & - & - & + & - & ++ & - & - & - & - & - & - \\
\hline Urinary bladder & - & - & - & - & - & - & - & - & - & - & +++ & - & - & - & - & - & - \\
\hline
\end{tabular}

Cardiovascular lesions were also frequent and were characterized by epicardial and endocardial hemorrhages. The endocardial hemorrhagic areas commonly involved the left ventricle, near insertion of the chordae tendineae, in the papillary muscle (Fig.4A). Hemorrhages in the mitral valve and in the base of pulmonary artery were seldom observed (Fig.4B). Hydropericardium was observed in only two sheep.

Lymph nodes, mainly the mesenteric and mediastinal were occasionally enlarged. Gross lesions in the skeletal muscle were rare, seen in one sheep, and characterized by muscle fibers alternating pale areas with hemorrhagic areas. In the same sheep, the urinary bladder was distended and with the wall markedly hemorrhagic. Gross lesions were not observed in the kidneys, liver, spleen, intestine and brain. The severity of the gross lesions of each sheep is described in Table 2.

\section{Histological lesions}

The lesions in the lung, esophageal striated muscle, and cardiac and skeletal muscle, mainly in the neck and forelimbs, were the most frequent. The pulmonary lesion was characterized by the presence of hyaline material within the alveoli, bronchioles and bronchi (edema). This lesion was commonly associated with fibrinosuppurative bronchopneumonia, with alveoli, bronchioles and bronchi filled by intact and degenerate neutrophils and fibrin, and, not infrequently, by vegetable fibers (Fig.5A) and intralesional bacterial aggregates. Occasionally, large areas of pulmonary parenchymal necrosis were seen in severe cases, and, commonly, the interlobular septa were mildly thickened and the capillaries of alveolar septa were congested.

In esophageal striated muscles there was hyaline and flocculate degeneration and necrosis, characterized, respectively, by rounded and hypereosinophilic muscle fibers with pyknotic nuclei or fragmented fibers. There was inflammatory infiltrate predominantly lymphohistiocytic dissecting the muscle fibers or forming aggregates around of necrotic fibers. Also, multifocal areas of hemorrhage and mineralization of necrotic fibers were observed (Fig.5B), which were occasionally surrounded by multinucleated giant cells. Identical lesions were also observed in the skeletal muscles (Fig.5C), tongue and heart. However, hemorrhagic areas in the heart were more extensive, affecting mainly the miocardium (Fig.5D), extending to the endocardium and epicardium. There was transmural hemorrhage 
affecting the base of pulmonary artery. All of these tissues had endothelial hypertrophy of blood vessels, and, in some cases, fibrinoid vascular necrosis in the heart (Fig.5E), esophagus, lungs and tongue.

Other common lesions were associated with the oral cavity, involving mainly the lips, hard palate, oral conic buds, and tongue. On the lips, in both hairy and hairless portions, there were subcutaneous edema and perivascular aggrega- tes of lymphocytes and macrophages, as well as hemorrhagic areas. Rumen and reticulum have erosion and ulceration of the lining epithelium. Ulcers and erosions were covered by fibrin, intact and degenerate neutrophils, erythrocytes, and cell debris (Fig.5F) and, commonly, showed vacuolar degeneration of adjacent epithelial cells. Hemorrhagic areas and lymphohistiocytic and neutrophilic perivascular inflammatory infiltrate were common in the dermis/lamina

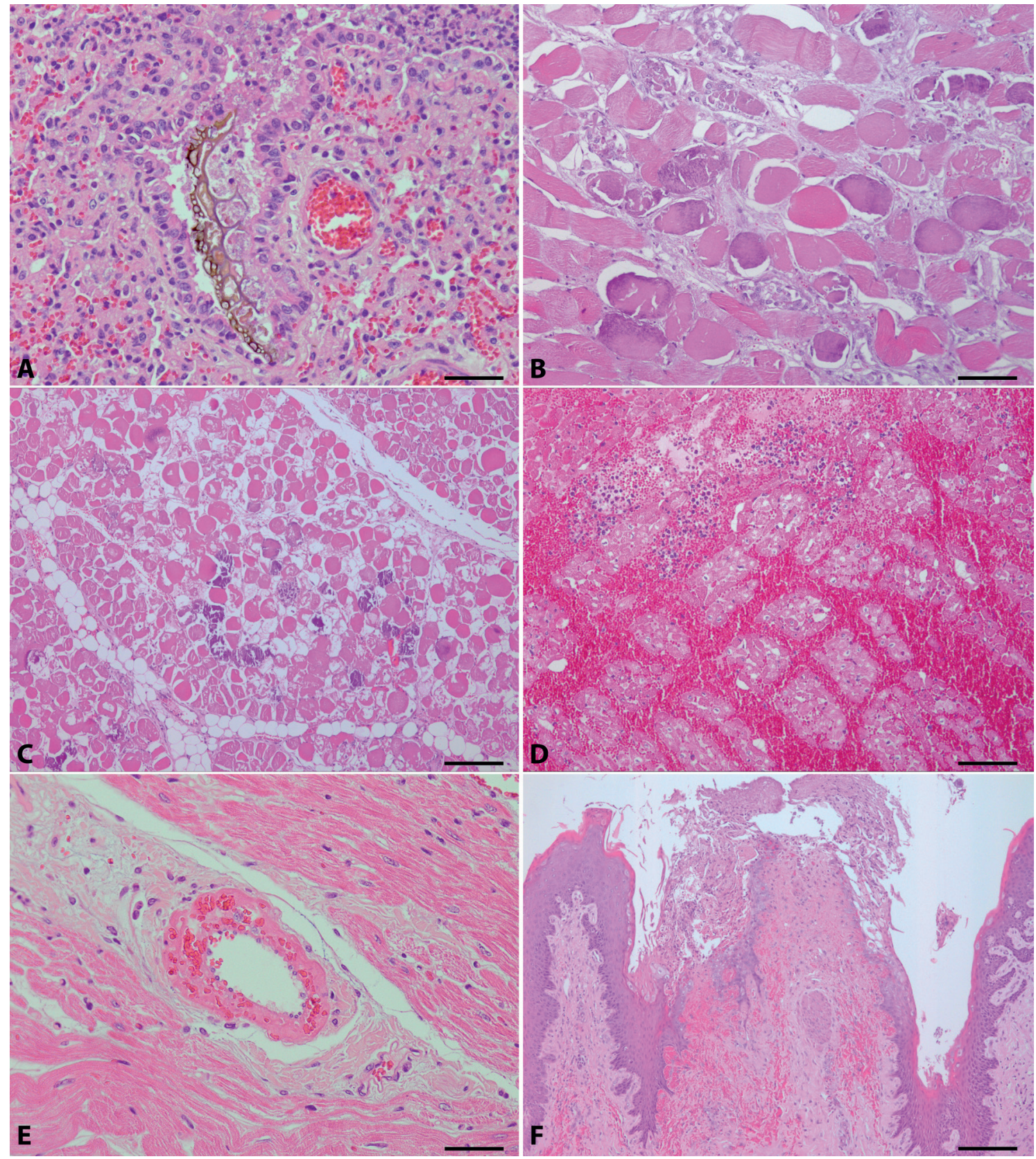

Fig.5. Bluetongue in sheep. (A) Lung. Birrefringent, and greenish-brown material within a bronchiole (vegetable fiber). Note there are lots of fibrin, and intact and degenerate neutrophils around the fiber, and adjacent alveoli. HE, obj.40x. (B) Esophagus. Hyaline and flocculate degeneration and necrosis of myofibers. Note there is mineralization of necrotic fibers, and some of them are surrounded by lymphocytes and macrophages. HE, obj.20x. (C) Skeletal muscle. Hyaline and flocculate degeneration and necrosis of myofibers with mineralization of necrotic fibers. HE, obj.10x. (D) Heart. Extensive hemorrhagic areas in the miocardium dissecting the muscle fibers. Note there is neutrophilic inflammatory infiltrate through the hemorrhage. HE, obj.20x. (E) Heart and blood vessel. Marked hyalinization of the arteriole wall (fibrinoid vascular necrosis). HE, obj.40x. (F) Reticulum. Marked ulceration of lining epithelium. Note the ulcerated area is covered by fibrin, intact and degenerate neutrophils, erythrocytes, and cellular debris. There is also hemorrhage extending into the submucosa. HE, obj.10x. 
Table 3. Distribution and severity of histological lesions

\begin{tabular}{|c|c|c|c|c|c|c|c|c|c|c|c|c|c|c|c|c|c|}
\hline Sheep & $\mathrm{S} 1$ & S2 & S3 & $\mathrm{S} 4$ & S5 & S6 & S7 & S8 & S9 & $\mathrm{S} 10$ & S11 & S12 & $\mathrm{S} 13$ & S14 & S15 & S16 & S17 \\
\hline \multicolumn{18}{|l|}{ Organs } \\
\hline Lips & $\mathrm{NE}$ & $\mathrm{NE}$ & $\mathrm{NE}$ & $\mathrm{NE}$ & ++ & NE & ++ & $\mathrm{NE}$ & + & NE & ++ & ++ & ++ & + & + & ++ & - \\
\hline Hard palate & $\mathrm{NE}$ & $\mathrm{NE}$ & $\mathrm{NE}$ & $\mathrm{NE}$ & +++ & $\mathrm{NE}$ & +++ & ++ & $\mathrm{NE}$ & NE & +++ & - & - & - & - & - & - \\
\hline Tongue & $\mathrm{NE}$ & $\mathrm{NE}$ & +++ & ++ & ++ & ++ & ++ & ++ & - & NE & ++ & + & - & - & ++ & - & - \\
\hline Cheeks & $\mathrm{NE}$ & $\mathrm{NE}$ & $\mathrm{NE}$ & $\mathrm{NE}$ & ++ & NE & ++ & NE & $\mathrm{NE}$ & NE & ++ & - & - & - & - & - & - \\
\hline Esophagus & NE & $\mathrm{NE}$ & +++ & ++ & ++ & +++ & +++ & ++ & ++ & + & ++ & +++ & +++ & ++ & + & + & + \\
\hline Rumen & $\mathrm{NE}$ & $\mathrm{NE}$ & - & - & +++ & - & ++ & ++ & ++ & $\mathrm{NE}$ & +++ & - & - & - & - & - & +++ \\
\hline Reticulum & $\mathrm{NE}$ & $\mathrm{NE}$ & - & $\mathrm{NE}$ & ++ & - & - & + & - & $\mathrm{NE}$ & - & - & - & - & - & - & - \\
\hline Omasum & $\mathrm{NE}$ & $\mathrm{NE}$ & - & $\mathrm{NE}$ & + & - & - & - & - & NE & - & - & - & - & - & - & - \\
\hline Intestine & $\mathrm{NE}$ & $\mathrm{NE}$ & - & ++ & - & - & ++ & + & - & $\mathrm{NE}$ & - & - & - & + & - & - & - \\
\hline Heart & - & - & ++ & + & +++ & ++ & +++ & ++ & ++ & $\mathrm{NE}$ & +++ & ++ & ++ & ++ & + & ++ & + \\
\hline Pulmonary artery & $\mathrm{NE}$ & $\mathrm{NE}$ & ++ & $\mathrm{NE}$ & +++ & ++ & +++ & + & - & $\mathrm{NE}$ & +++ & + & - & + & + & - & - \\
\hline Lung & + & +++ & ++ & ++ & ++ & +++ & - & + & + & + & +++ & ++ & +++ & +++ & +++ & ++ & +++ \\
\hline Skeletal muscles & $\mathrm{NE}$ & $\mathrm{NE}$ & ++ & $\mathrm{NE}$ & ++ & +++ & ++ & +++ & +++ & NE & +++ & + & + & + & + & + & + \\
\hline Spleen & $\mathrm{NE}$ & $\mathrm{NE}$ & ++ & - & ++ & - & + & + & - & NE & + & - & - & - & - & - & - \\
\hline Lymph nodes & $\mathrm{NE}$ & $\mathrm{NE}$ & $\mathrm{NE}$ & - & ++ & ++ & ++ & ++ & + & $\mathrm{NE}$ & ++ & - & - & - & - & - & - \\
\hline Liver & - & ++ & - & - & - & - & - & - & ++ & NE & - & + & - & - & - & - & - \\
\hline Kidneys & + & - & - & - & - & - & + & - & - & NE & + & - & + & - & - & - & - \\
\hline Urinary bladder & $\mathrm{NE}$ & $\mathrm{NE}$ & $\mathrm{NE}$ & $\mathrm{NE}$ & NE & NE & NE & NE & $\mathrm{NE}$ & NE & +++ & - & - & - & - & - & - \\
\hline
\end{tabular}

$\overline{\mathrm{NE}}=$ not examined, + mild lesion, ++ moderate lesion, +++ severe lesion.

Table 4. Sheep subjected to necropsy and type of sample sent to RT-PCR assay

\begin{tabular}{|c|c|c|c|}
\hline Outbreak & Necropsy & PCR of tissue & PCR of blood \\
\hline 1 & Yes & + & UR \\
\hline 1 & Yes & + & + \\
\hline 1 & No & UR & + \\
\hline 2 & Yes & UR & UR \\
\hline 2 & Yes & UR & UR \\
\hline 2 & Yes & UR & UR \\
\hline 2 & Yes & UR & + \\
\hline 2 & Yes & + & UR \\
\hline 2 & Yes & UR & UR \\
\hline 2 & No & UR & + \\
\hline 3 & Yes & + & + \\
\hline 4 & No & UR & + \\
\hline 5 & No & UR & + \\
\hline 6 & Yes & + & + \\
\hline 7 & No & UR & + \\
\hline 8 & No & UR & + \\
\hline 9 & No & UR & + \\
\hline 10 & No & UR & + \\
\hline 11 & Yes & UR & UR \\
\hline 11 & No & UR & + \\
\hline 12 & Yes & + & UR \\
\hline 12 & Yes & UR & UR \\
\hline 13 & No & UR & + \\
\hline 14 & No & UR & + \\
\hline 15 & Yes & + & UR \\
\hline 16 & Yes & + & UR \\
\hline 16 & Yes & + & UR \\
\hline 17 & Yes & + & UR \\
\hline
\end{tabular}

$\overline{\mathrm{UR}}=$ unrealized, + positive result.

propria. In these tissues, endothelial swelling of blood vessels was also frequent.

Lesions in the lymph nodes and spleen were common and characterized by lymphoid nodular hyperplasia. Other less frequent changes were observed in the kidneys, liver, urinary bladder and intestine and were characterized, respectively, by multifocal tubular necrosis, centrilobular and paracentral hepatic necrosis, necrohemorrhagic cystitis, and lymphocitic and eosinophilic enteritis. Histological le- sions were not observed in the abomasum and brain. The severity of the histological lesions of each sheep is described in the Table 3 .

\section{Virological findings}

A total of 25 samples of blood $(n=15)$, spleen and lungs $(n=10)$ from several sheep from different outbreaks were positive to BTV by RT-PCR. Sheep subjected to necropsy and the type of sample sent to RT-PCR assay of each outbre$\mathrm{ak}$, and the results of this test are described in the Table 4 . The BTV serotype 17 was isolated from one spleen sample from the outbreak 3.

\section{DISCUSSION}

Similarly to other authors (Clavijo et al. 2002, Navarre et al. 2002, Radostits et al. 2007, Riet-Correa 2007, Antoniassi et al. 2010, Alfieri et al. 2012, Balaro et al. 2014, Lima et al. 2016), the diagnosis of BT in these outbreaks was based on clinical, pathological and epidemiological findings, and confirmed by detection of BTV RNA by RT-PCR. Epidemiologically, factors related to the virus, the vector, the environment and the host may influence the occurrence and severity of the outbreaks (Gibbs \& Greiner 1994, Maclachlan 1994, Radostits et al. 2007, Williamson et al. 2008, Alfieri et al. 2012). Viruses of the BT serogroup are characterized by a remarkable genetic diversity (Maclachlan 1994), with differences in virulence between serotypes and viral strains (Radostits et al. 2007). Furthermore, due to the fact that the disease is not contagious, the insect vector is fundamental to the transmission and survival of the virus, and the BTV infection only occurs when competent vectors are present (Maclachlan 1994, Radostits et al. 2007).

The weather conditions are a major risk factor for the occurrence of BT (Radostits et al. 2007, Gould \& Higgs 2009). Vector-borne diseases are highly sensitive to changes in weather and climate and can affect the geographical distribution and incidence of them (Medlock \& Leach 2015). BT clearly occurs in areas with conditions that favor the 
proliferation of the insect vectors. These include hot climate areas, with high humidity, and a desirable environment for the development of mosquito larvae, such as stagnant water with organic matter (Maclachlan 1994, Radostits et al. 2007). Warm and rainy seasons favor the appearance of Culicoides and therefore the transmission of the virus (Barnard et al. 1998, Alfieri et al. 2012). Thus, in temperate zones, also called epidemic areas, the outbreaks are often seasonal. The disease is usually seen during the summer and early autumn and outbreaks cease after the first frost of winter (Gibbs \& Greiner 1994, Maclachlan 1994, Riet-Correa 2007, Maclachlan 2011). This has been observed in the outbreaks described herein, which occurred during the summer until early winter. In addition, environmental factors favorable to the vector, such as rainy and hot spring and summer, and less cold winter, were observed in the RS in the years 2014 and 2015 (Centro Estadual de Meteorologia CEMETRS 2015). The RS has the lowest prevalence of the disease in Brazil (Costa et al. 2006), probably due to the subtropical climate, that is not favorable to the vector survivor during winter. However, the presence of vector and an extensive population of susceptible hosts, associated to climate changes in the area, such as increase of the average of annual precipitation and minimum temperatures, characterize the state as an area of risk for occurrence of BTV outbreaks (Costa et al. 2006, Alfieri et al. 2012).

Host factors that influence the severity of the disease included immune and nutritional status, stress, exposure to ultraviolet radiation, breed, and age (Gibbs \& Greiner 1994, Maclachlan 1994, Radostits et al. 2007, Maclachlan et al. 2009). Gibbs \& Greiner (1994) and Maclachlan (1994) consider that sheep older than 3-4 years are most affect by BT. However, we observed that lambs under one year of age had higher morbidity, mortality and lethality rates than sheep with one year-old or more. In addition, factors such as intensive management, low nutritional scores, and severe endoparasitism (Haemonchus contortus) may have contributed to the infections and clinical disease in some farms. These factors can weaken the sheep immune system, impairing an adequate immune response against the virus.

The morbidity and mortality rates can vary significantly among outbreaks (Maclachlan et al. 2009). When the disease occurs for the first time in a herd, the morbidity may reach to $50-75 \%$ and the mortality $20-50 \%$ (Radostits et al. 2007, Riet-Correa 2007). However, typically the mortality rate rarely exceeds $30 \%$ (Maclachlan et al. 2009), and remains in 1-10\% (Guedes et al. 2010). In the reported outbreaks there was a wide variation in the morbidity, mortality and lethality rates, similar to reported in the literature.

The clinical signs and the duration of clinical manifestations observed in these outbreaks were similar to those described by several authors (Clavijo et al. 2002, Navarre et al. 2002, Radostits et al. 2007, Riet-Correa 2007, Elbers et al. 2008, Williamson et al. 2008, Maclachlan et al. 2009, Antoniassi et al. 2010, Guedes et al. 2010, Alfieri et al. 2012, Balaro et al. 2014, Lima et al. 2016). Fever was described in less than half of the outbreaks. Clinical signs such as anorexia, lethargy, severe weight loss, facial swelling (mainly involving the lips), and greenish seromucous or mucous nasal discharge, seen in all outbreaks, were fundamental to the suspicion of BT in the absence of more characteristic clinical signs, such as ulcerative lesions in the oral cavity.

The gross and histological lesions observed in these outbreaks were also similar to those described by several authors (Clavijo et al. 2002, Radostits et al. 2007, Riet-Correa 2007, Williamson et al. 2008, Maclachlan et al. 2009, Antoniassi et al. 2010, Guedes et al. 2010, Alfieri et al. 2012, Balaro et al. 2014, Lima et al. 2016). The virus replicates in endothelial cells of capillaries and small blood vessels, causing degenerate, necrotic, and hyperplasic changes in the endothelium, which result in increased of vascular permeability and causing edema, congestion, hemorrhage, thrombosis and necrosis (Radostits et al. 2007, Williamson et al. 2008, Maclachlan et al. 2009). Furthermore, the virus indirectly induces the release of vasoactive and inflammatory mediators by host cells, mainly platelets, macrophages, dendritic and endothelial cells. This contributes to a worsening of endothelial dysfunction and vascular damage (Maclachlan et al. 2009).

Histological lesions generally reflect the gross changes (Maclachlan et al. 2009). This aspect was observed in these outbreaks, however, there was divergence between esophageal and skeletal muscle lesions. Gross lesions in the esophagus were observed in three cases, and in skeletal muscle in only one. However, histological changes, characterized by degeneration and necrosis of myofibers, were present in almost all cases.

Pulmonary edema was a very important lesion observed in almost all necropsied sheep. This is a characteristic lesion of fulminant BT (Maclachlan et al. 2009) and it was probably the main cause of death. Many sheep also had aspirative pneumonia as a result of aspiration of regurgitated food content. This change occurs by paralysis of the esophagus due to muscle lesion induced by the virus (Radostits et al. 2007).

Cardiac hemorrhages and necrosis also were frequent, mainly seen on the left ventricle endocardium and papillary muscle. The papillary muscle of the left ventricle is considered as a characteristic location for the occurrence of this lesion (Maclachlan et al. 2009). Hemorrhage at the base of the pulmonary artery, considered a particular finding of BT, is described as an infrequent lesion (Antoniassi et al. 2010, Guedes et al. 2010, Alfieri et al. 2012, Lima et al. 2016), but it was observed in about half of the necropsied sheep. Erosive and ulcerative lesions in the upper digestive tract also are characteristic of BT and affect mainly the oral cavity, esophagus and forestomachs (Maclachlan et al. 2009). These characteristics changes were common in the outbreaks here described, and were helpful to suspect of the disease.

The diagnosis of BT was confirmed by RT-PCR assay using blood and tissues (spleen and lung) samples. These are the most important targets for BTV detection due to its tropism and pathogenesis (Maclachlan et al. 2009, Maclachlan 2011). The BTV serotype 17 was isolated from one spleen sample from the outbreak 3. This is the first report of this BTV serotype in Brazil.

The differential diagnosis for BT should be done with other diseases causing edema, hemorrhage, and epithelial damage (Williamson et al. 2008). In sheep it should include 
mainly contagious ecthyma, foot-and-mouth disease, and vesicular stomatits (Riet-Correa 2007, Williamson et al. 2008, Alfieri et al. 2012). Furthermore, lesions such as muscle necrosis associated with mineralization may resemble nutritional muscle dystrophy (NMD), caused by deficiency of vitamin E and selenium. However, NMD is characterized by white areas in large muscle groups with chalk powder appearance in the muscle surface (Antoniassi et al. 2010).

Supportive treatment is the only option. Broad-spectrum antibiotics are indicated to avoid secondary bacterial infections. Non-steroidal anti-inflammatory drugs are also indicated for controlling inflammation, fever, and pain. Nutritional and fluid support may be needed if the affect animals cannot eat or drink (Navarre et al. 2002). In many farms, the veterinarians responsible for the animal care, recommended the administration of broad-spectrum antibiotics, associated with non-steroidal anti-inflammatory drugs, once a day for 3-5 days. This treatment is very important in cases that sheep develop aspirative pneumonia.

Control of BTV infection is complicated by the plurality of virus serotypes and the ubiquity and feeding behavior of its midge vector (Maclachlan \& Mayo 2013). Furthermore, as BTV infection can occur without clinical manifestations, particularly in cattle, the infection can spread unnoticed. Thus, the measures that can be adopted are aimed at minimizing the damage caused by the clinical disease (Alfieri et al. 2012). Control can be done by reducing the vector population using insecticides, although this technique has been shown to be impractical for routine use and may result in environmental problems, besides being very expensive and economically unviable. Restrictive measures for the ruminant introduction in the farms should also be adopted. Such animals must be keep in quarantine and have animal health certificate with negative results for viral isolation or PCR assay from blood samples (Radostits et al. 2007, Alfieri et al. 2012, Maclachlan \& Mayo 2013). Vaccination is a preventive measure most used in countries where BT is an important sanitary problem. However, in Brazil there are no licensed vaccines (Alfieri et al. 2012). Recovered animals are resistant to reinfection with homologous virus serotype, which is the basis for vaccination strategies to prevent BTV infection and the clinical disease (Maclachlan et al. 2014).

\section{CONCLUSION}

Our results support that the central region of Rio Grande do Sul should be considered an area at risk for Bluetongue in sheep and may deserve attention from veterinarians and official animal services.

\footnotetext{
Acknowledgements.- The authors would like to acknowledge Veterinarian Rodrigo Machado Leon, for his assistance in carrying out the clinical and epidemiological assessment of some outbreaks, and Dr. Zelia Ines Portela Lobato for the identification of BTV serotype. R.M. Bianchi, and T.C. Faccin are research fellowship of Capes. W. Panziera, and J.F. Cargnelutti are research fellowship of CNPq.
}

\section{REFERENCES}

Alfieri A.A., Alfieri A.F., Matos A.C.D., Lorenzetti E. \& Lobato Z.I.P. 2012. Reoviridae, p.897-940. In: Flores E.F. (Ed.). Virologia Veterinária. 2ª ed. Editora UFSM, Santa Maria. 1007p.
Anthony S., Jones H., Darpel K.E., Elliott H., Maan S., Samuel A., Mellor P.S. \& Mertens P.P.C. 2007. A duplex RT-PCR assay for detection of genome segment 7 (VP7 gene) from 24 BTV serotypes. J. Virol. Methods. 141:188197.

Antoniassi N.A.B., Pavarini S.P., Ribeiro L.A.O. Silva M.S., Flores E.F. \& Driemeier D. 2010. Alterações clínicas e patológicas em ovinos infectados naturalmente pelo vírus da língua azul no Rio Grande do Sul. Pesq. Vet. Bras. 30:1010-1016.

Balaro M.F.A., Lima M.S., Fava C.D., Oliveira G.R., Pituco E.M. \& Brandão F.Z. 2014. Outbreak of bluetongue virus serotype 4 in dairy sheep in Rio de Janeiro, Brazil. J. Vet. Diagn. Invest. 26:567-570.

Barnard B.J.H., Gerdes G.H. \& Meiswinkel R. 1998. Some epidemiological and economic aspects of a bluetongue-like disease in cattle in South Africa, 1995/96 and 1997. Onderstepoort J. Vet. Res. 65:145-151.

Caporale M., Wash R., Pini A., Savini G., Franchi P., Golder M., Patterson-Kane J., Mertens P., Gialleonardo L.D., Armillotta G., Lelli R., Kellam P. \& Palmarini M. 2011. Determinants of bluetongue virus virulence in murine models of disease. J. Virol. 85:11479-11489.

CEMETRS. 2015. Boletins meteorológicos do Estado do Rio Grande do Sul. Secretaria da Agricultura Pecuária e Agronegócio, Governo do Estado do Rio Grande do Sul. Available in <http://www.cemet.rs.gov.br/lista/218/ Boletim_Meteorol\%C3\%B3gico_Mensal> Acess on May 10, 2015.

Clavijo A., Sepulveda L., Riva J., Pessoa-Silva M., Tailor-Ruthes A. \& Lopez J.W. 2002. Isolation of bluetongue virus serotype 12 from an outbreak of the disease in South America. Vet. Rec. 151:301-302.

Costa J.R.R., Lobato Z.I.P., Herrmann G.P., Leite R.C. \& Haddad J.P.A. 2006. Prevalência de anticorpos contra o vírus da língua azul em bovinos e ovinos do sudoeste e sudeste do Rio Grande do Sul. Arq. Bras. Med. Vet. Zootec. 58:273-275.

Elbers A.R.W., Backx A., Meroc E., Gerbier G., Staubach C., Hendrickx G., Spek A. \& Mintiens K. 2008. Field observations during de bluetongue serotype 8 epidemic in 2006. I. Detection of first outbreaks and clinical signs in sheep and cattle in Belgium, France and the Netherlands. Prev. Vet. Med. 87:21-30.

Gibbs E.P. \& Greiner E.C. 1994. The epidemiology of bluetongue. Comp. Immun. Microbiol. Infect. Dis. 17:207-220.

Gould E.A. \& Higgs S. 2009. Impact of climate and other factors on emerging arbovirus diseases. Trans. R. Soc. Trop. Med. Hyg. 103:109-121.

Groocock C.M. \& Campbell C.H. 1982. Isolation of an exotic serotype of bluetongue virus from imported cattle in quarantine. Can. J. Comp. Med. 46:160-164.

Guedes R.M.C., Brown C.C. \& Sequeira J.L. 2010. Sistema digestório, p.89182. In: Santos R.L. \& Alessi A.C. (Eds), Patologia Veterinária. Roca, São Paulo. 892p.

Guimarães L.L.B. 2015. Achados clínicos e patológicos de sete surtos de língua azul em ovinos em 2014 no Rio Grande do Sul, Brasil. Dissertação de Mestrado, Programa de Pós-Graduação em Ciências Veterinárias, Universidade Federal do Rio Grande do Sul (UFRGS), Porto Alegre. 63p.

Jenckel M., Bréard M., Schulz C., Sailleau C., Viarouge C., Hoffmann B., Höper D., Beer M. \& Zientara S. 2015. Complete coding genome sequence of putative novel bluetongue virus serotype 27. Genome A. 3:e00016-15.

Lager I.A. 2004. Bluetongue virus in South America: overview of viruses, vectors, survillance and unique features. Vet. Ital. 40:89-93.

Lima P.A., Utiumi K.U., Nakagaki K.Y.R., Biihrer D.A., Albuquerque A.S., Souza F.R., Matos A.C.D., Lobato Z.I.P., Driemeier D., Peconick A.P., Varaschin M.S. \& Raymundo D.L. 2016. Diagnoses of ovine infection by the serotype-4 bluetongue virus on Minas Gerais, Brazil. Acta Sci. Vet. 44:1-5.

Lobão F.M., Melo C.B., Mendonça C.E.D., Leite R.C., McManus C., Krewer C.C. \& Uzêda R.S. 2014. Língua azul em ovinos: uma revisão. Revta Bras. Reprod. Anim. 38:69-74.

Maan N.S., Maan S., Belaganahalli M.N., Ostlund E.N., Johnson D.J., Nomikou K. \& Mertens P.P.C. 2012. Identification and differentiation of twenty six bluetongue virus serotypes by RT-PCR amplification of the serotype-specific genome segment 2. PloS One 7:e32601.

Maclachlan N.J., Jagels G., Rossitto P.V., Moore P.F. \& Heidner H.W. 1990. 
The pathogenesis of experimental bluetongue virus infection of calves. Vet. Pathol. 27:223-229.

Maclachlan N.J. 1994. The pathogenesis and immunology of bluetongue virus infection of ruminants. Comp. Immun. Microbiol. Infect. Dis. 17: 197-206.

Maclachlan N.J., Drew C.P., Darpel K.E. \& Worwa G. 2009. The pathology and pathogenesis of bluetongue. J. Comp. Pathol. 141:1-16.

Maclachlan N.J. 2011. Bluetongue: history, global epidemiology, and pathogenesis. Prev. Vet. Med. 102:107-111.

Maclachlan N.J. \& Mayo C.E. 2013. Potential strategies for control of bluetongue, a globally emerging, Culicoides, transmitted viral disease of ruminant livestock and wildlife. Antiv. Res. 99:79-90.

Maclachlan N.J., Henderson C., Schwartz-Cornil I. \& Zientara S. 2014. The immune response of ruminant livestock to bluetongue virus: from type I interferon to antibody. Virus Res. 182:71-77.

MAPA 2013. Instrução Normativa no. 50, de 24 de setembro de 2013. Diário Oficial da União. Avaliable in <www.agricultura.gov.br> Acess on April 19, 2015.

Medlock J.M. \& Leach S.A. 2015. Effect of climate change on vector-borne disease risk in the UK. Lancet Infect. Dis. 15:1-10.

Navarre C.B., Lowder M.Q. \& Pugh D.G. 2002. Oral-esophageal diseases, p.61-68. In: Pugh D.G. (Ed.), Sheep \& goat medicine. Saunders, Philadelphia. 468p.
OIE 2015. OIE-Listed diseases, infections and infestations in force in 2015. Avaliable in <http://www.oie.int/animal-health-in-the-world/oie-listed-diseases-2015> Acess on April 19, 2015.

OIE 2016. OIE, bluetongue, Brazil. Avaliable in <http://www.oie.int/wahis_2/public/wahid.php/Countryinformation/Countryreports> Acess on August 30, 2016.

Radostits O.M., Gay C.C., Hinchcliff K.W. \& Constable P.D. 2007. Diseases associated with viruses and Chlamydia I, p.1157-1305. In: Ibid (Eds.), Veterinary Medicine: a textbook of the diseases of cattle, horses, sheep, pigs and goats. 10th ed. Saunders Elsevier, Philadelphia. 2156p.

Riet-Correa F. 2007. Língua azul, p.169-173. In: Riet-Correa F., Schild A.L., Lemos R.A.A. \& Borges J.R. (Eds), Doenças de ruminantes e equídeos. Vol. 1. $3^{\text {a }}$ ed. Pallotti, Santa Maria. 719p.

Schulz C., Bréard E., Sailleau C., Jenckel M., Viarouge C., Vitour D., Palmarini M., Gallois M., Höper D., Hoffmann B., Beer M. \& Zientara S. 2016. Bluetongue virus serotype 27: detection and characterization of two novel variants in Corsica, France. J. Gen. Virol. 97(9):2073-2083.

Williamson S., Woodger N. \& Darpel K. 2008. Differential diagnosis of bluetongue in cattle and sheep. In Practice 30:242-251.

Zientara S., Sailleau C., Viarouge C., Höper D., Beer M., Jenckel M., Hoffmann B., Romey A., Bakkali-Kassimi L., Fablet A., Vitour D. \& Bréard E. 2014. Novel Bluetongue Virus in Goats, Corsica, France, 2014. Emerg. Infect. Dis. 20:2123-2125. 